\title{
ANALISIS DEMOKRASI HABERMAS PADA TEKS FORUM DISKUSI ONLINE RUU OMNIBUS LAW SEBAGAI DEMOKRASI
}

\author{
Nabila Sahma Libriyanti ${ }^{1}$, Novita ${ }^{2}$, Nada Syifafasya ${ }^{3}$,Dini Safitri ${ }^{4}$ \\ bnabila93@gmail.com ${ }^{1}, \underline{\text { novittaa04@gmail.com }}{ }^{2}$, nadasyifafasya303@gmail.com $^{3}$, \\ dinisafitri@unj.ac.id ${ }^{4}$ \\ Ilmu Komunikasi, Universitas Negeri Jakarta, Jl. Rawamangun Muka, RT.11/RW.14, \\ Rawamangun, Pulo Gadung, Kota Jakarta Timur, Daerah Khusus Ibukota Jakarta \\ 13220, Indonesia
}

Submitted: 20 Juni 2020| Accepted: 24 September 2020 | Published: 30 Desember 2020

Website: https://e-journal.umc.ac.id/index.php/jike/index

\begin{abstract}
According to habermas, public space is a space where citizens can negotiate about their relations so that it is an institutional arena for interaction. The development of increasingly advanced communication media has resulted in a large amount of public space being carried out online through social media to discuss public issues with the aim of creating a democracy. This study aims to determine the analysis of habermas democracy in the text of the online discussion forum of the omnibus law ruu as democracy. The labor law omnibus is still a polemic in the community because on the one hand it is considered to be beneficial for employers and increasingly marginalizes workers / laborers with an hourly wage system plan which is considered by workers to weaken the position and welfare of workers / workers. This research uses analytical methods in the perspective of communication on deliberative democracy and based on two habermas theories of Structural Transformation of Public Spaces \& Between Facts and Norms. This discourse analysis model is based on 3 blades of communicative action analysis that includes 3 claims. The data collection technique is a text method in the form of opinions submitted by members of the online discussion group "Work Draft Bill: Threatening Indonesian Employment and Agriculture" and "Work Draft Bill: Breaking Through Indonesian Law?". Each argument / opinion is analyzed based on three validity claims, namely: truth. accuracy, and honesty. The results of this study are based on text analysis that burdensome parties from laborers, students, farmers, fishermen, indigenous peoples, rural and urban residents, and prioritizes the interests of investors and entrepreneurs
\end{abstract}

Keywords:, Democracy, Omnibus law, Public space

\begin{abstract}
Abstrak
Menurut habermas ruang publik merupakan ruang dimana warga Negara dapat berunding mengenai hubungan mereka sehingga merupakan sebuah arena institusi untuk berinterkasi. Berkembangnya media komunikasi yang semakin maju menimbulkan banyaknya ruang publik yang dilakukan secara daring melalui sosial media untuk mendiskusikan isu-isu publik dengan tujuan untuk menciptakan sebuah demokrasi. Penelitian ini bertujuan untuk mengetahui analisis demokrasi habermas pada teks forum diskusi online ruu omnibus law sebagai demokrasi. Omnibus law ketenagakerjaan sampai saat ini masih menjadi polemik di masyarakat karena di satu sisi dianggap banyak menguntungkan para pengusaha dan semakin memarjinalkan pekerja/buruh dengan rencana sistem upah per-jam yang oleh pekerja dianggap akan memperlemah posisi dan kesejahteraan para buruh/pekerja. Penelitian ini menggunakan metode analisis dalam perspektif komunikasi pada demokrasi deliberatif dan berdasarkan dua teori habermas Transformasi Struktural Ruang Publik \& Antara Fakta dan Norma. Model analisis wacana ini berdasarkan pada 3 pisau analisis tidakan komunikatif yang mencakup 3 klaim. Teknik pengumpulan data yaitu metode teks berupa pendapat yang disampaikan oleh para anggota grup diskusi online "RUU Cipta Kerja: Mengancam Ketenagakerjaan Dan Agraria Indonesia" dan "RUU Cipta Kerja: Menerobos Hukum Indonesia?". Setiap argumen/pendapat
\end{abstract}


dianalisis dengan berdasar pada tiga klaim validitas, yaitu: kebenaran. ketepatan, dan kejujuran. Hasil dari penelitian ini berdasarkan analisis teks bahwa memberatkan pihak dari golongan buruh, mahasiswa, petani, nelayan, masyarakat adat, penduduk desa maupun kota, dan lebih mengedepankan kepentingan investor dan pengusaha

Kata Kunci :Demokrasi, Omnibus Law, Ruang Publik

\section{A. PENDAHULUAN}

Ruang publik (public sphere) digambarkan oleh seorang filsuf Jerman Habermas sebagai sebuah ruang dimana masyarakat dalam sebuah lingkungan membuat sebuah opini publik terkait dengan kondisi sosial politik atau ekonomi. Keberadaan public sphare sendiri sudah ada sejak 1700an saat masyarakat barat seperti Perancis dan Amerika ulai melakukan revolusi yang dimana warga masyarakat biasa dilibatkan dalam berbagai proses diskusi publik untuk membuat suatu keputusan mengenai berbagai persoalan yang ada dalam publik. Akan tetapi, ruang publik pada masa itu dilihat oleh Habermas hanya sebagai sebuah ruang yang dikuasi oleh kelompok-kelompok borjuis, dimana tidak seluruh elemen warga negara memiliki suara yang setara (Pembayun, 2017).

Demokrasi secara ideal dianggap dapat menyediakan tempat bagi segenap rakyat untuk terlibat dalam hal menyuarakan aspirasi di tengah beragamnya unsur penyusun sebuah negara. Tetapi, saat ini demokrasi malah terlihat lebih jelas diartikan sebagai superioritas jumlah dan tekanan arus pendapat mayoritas identitas yang beralih menjunjung tinggi kesetaraan dalam hal unjuk aspirasi di ruang publik (Sukmono, 2009). Hal tersebut menyebabkan munculnya sebuah ideologi yang terasumsikan ke dalam bentuk varian baru yaitu demokrasi deliberatif. Faktor determinan dalam hal ajang deliberasi yaitu komunikasi. Demokrasi deliberatif secara umum menekankan penalaran lewat dialog, pertukaran pendapat, yang bertujuan untuk menghasilkan ragam hasil yang bisa diterapkan karena persetujuan kolektif.

Berkembangnya media komunikasi yang semakin maju menimbulkan banyaknya ruang publik yang dilakukan secara daring melalui sosial media untuk mendiskusikan isu-isu publik dengan tujuan untuk menciptakan sebuah demokrasi. Namun Asep A. Sahid Gatara dalam penelitiannya yang berjudul "Demokrasi Nothing Kritik Terhadap Konsep Dan Praktek Cyberdemocracy" menggambarkan secara kritis mengenai gejala kontestasi politik yang bisa berlangsung secara online yang dapat dikatakan sebagai wujud perkembangan dari cyberdemocracy (Gatara, 2016). Sebelumnya pernah dilakukan penelitian oleh Wasisto Raharjo Jati dengan judul penelitian Cyberspace, internet, dan Ruang publik baru: Aktivisme Online Politik Kelas Menengah Indonesia. Munculnya sosial media memunculkan ruang publik baru secara keseluruhan. Hal tersebut menawarkan adanya deliberasi pada nilai-nilai demokrasi baru. Beberapa nilai demokrasi dideliberasikan melalui sosial media. Cyberspace juga dapat menarik bagi setiap bagian publik untuk berinteraksi dan berkomunikasi kapanpun dan dimanapun. Karena itulah kesadaran untuk politik tercipta (Jati, 2016)

Menurut Sahid, tidak semua ekspresi diruang virtual dapat dikatakan cyberdemocracy karena suatu situs dapat dikatakan cyberdemocracy apabila terdapat ruang public didalamnya. Tulisan ini juga membahas tentang term cyberdemocracy dimana diruang virtual kehadiran demokrasi menjadi lain dalam penyebutan citra maupun dala pemaknaan datau konsepnya, di mana ia popular terutama dalam lingkungan neo-futuris atau kaum optimis. Sahid berfokus pada komentar online Kompas.com pada saat pilpres 2014. Penelitian ini menghasilkan kesimpulan bahwa cyberdemocracy bukanlah demokrasi karena tidak ditemukan iklim debat rasional atau deliberasi publik dan proses pertukaran pengetahuan; tidak ditemukan iklim komunikasi yang 
terbabas dari dimensi dominasi; juga tidak ditemukan proses konsensus, di mana ketegangan yang ada dikelola dan diterima semua pihak, serta ide dan informasi yang digunakan secara bersama-sama (Sahid, 2016). ruang publik di dalam dunia nyata sudah banyak hilang dikarenakan berbagai kepentingan, baik itu kepentingan individu, golongan, maupun kepentingan kapitalisme yang mengakibatkan mempersempit ruang publik untuk berkembang. (Sukmono, 2009)

Proses demokrasi yang berlangsung dalam dunia virtual dijuluki Cyberdemocracy, yakni komunitas virtual yang memiliki aturan sendiri. Di sini demokrasi hidup di dunia virtual dengan mediasi internet. Seperti halnya demokrasi di ruang aktual, cyberdemocracy atau demokrasi cyber hanya bisa bertahan ketika adanya ruang publik, khususnya ruang publik dalam internet (ruang publik virtual). Dan memang ruang publik virtual merupakan pra-syarat bagi berkeberlangsungan demokrasi cyber. Di ruang itu terdapat nilai dan praktik konektivitas, intraktivitas dan anonimitas, sehingga memproduksi asas langsung, komunikatif, bebas dan rahasia. Dalam demokrasi politik di ruang aktual, sejatinya asas-asas tersebut juga telah lebih awal menjadi keharusan.Pada penelitian yang berjudul demokrasi nothing kritik terhadap konsep dan praktek cyberdemocray bertujuan untuk menggambarkan secara kritis mengenai gejala kontestasi politik yang tidak lagi hanya berlangsung di ruang offline, namun juga berlangsung dan semakin bergeser ke ruang online. Pergeseran kontestasi politik di ruang online itu banyak dikatkan sebagai salah satu wujud dari perkembangan cyberdemocracy.Hasilnya Kehadiran media baru tak terelakan karena itu cyberdemocracy adalah sebuah keniscayaan. Akan tetapi fakta menunjukkan, bahwa pada tahap awal sekarang ini, cyberdemocracy di Indonesia masih embrional dan masih diwarnai oleh praktik politik vulgar yang kurang mengindahkan etika berpolitik. Pemanfaatan media online, terutama pada media sosial, yang mestinya menjadi bagian dari pencerdasan politik warga, namun pada kenyataanya masih diwarnai praktik politik yang penuh dengan ujaran kebencian, dan bahkan juga kampanye negatif (Gatara, 2016).

Untuk menuju ruang publik ideal melalui era digital memiliki banyak tantangan. Terutama pada saat audiens dalam ruang publik tidak cukup rasional dalam memberikan argumentasi dan terjadinya kemungkinan pertukaran informasi yang tidak dapat dipertanggungjawabkan kebenaranya (Pembayun 2017). Pemerintah memberitahu ada 82 UU yang berpengaruh oleh omnibus law dan permerintah sudah mengajukan draft omnibus law ke DPR pada 2019. Tetapi rencana tersebut mundur hingga januari 2020. Omnibus law terdiri dari tiga prospek, yaitu perpajakan, cipta lapangan kerja, dan Usaha Kecil Menengah dan Mikro (UMKM). Pembahasan mengenai omnibus law ketenagakerjaan sampai saat ini masih menjadi kontroversi di masyarakat karena dianggap lebih banyak menguntungkan pengusaha dan mendesak para buruh/pekerja dengan rencana sistem upah per-jam yang dianggap membuat posisi dan kesejahteraan pekerja/buruh melemah. Omnibus law masih banyak pertentangan karena diduga aturan yang berbeda yang akan menyebabkan mengganggu sistem ketatanegaraan (Efendi, 2020). Oleh karena itu, peneliti memiliki keingintahuan mengenai bagaimana wujud ruang digital sekarang ini dan menganalisa bagaimana rekonstruksi ruang publik di era digital. Apakah sebuah diskusi publik yang diterapkan pada Omnibus Law benarbenar sesuai dengan difinisi diskusi publik menurut Jurgen Habermas dimana sebuah diskusi publik dikuasai oleh kelompok borjuis atau benar-benar mensinyalkan pada kebutuhan masyarakat. Dimana Omnibus Law akan disahkan sedangkan banyak komunitas-komunitas dalam masyarakat yang menolak diadakannya Omnibus Law ini karena beberapa hal dan alasan masing-masing kelompok. Banyaknya diskusi publik penolakan Omnibus Law komunitas-komunitas tertentu secara daring di media sosial salah satunya Diskusi Publik 
Online yang dilaksanakan oleh Red Soldier FIS UNJ dilaksanakan pada 20-21 Maret 2020 dengan pemantik diskusi Sujak Supriyadi dari Ka. Seni dan Budaya DPP-GBSI serta Aprillia Lisa Tengker dari Pengacara Publik LBH Jakarta.

\section{B. TINJAUAN PUSTAKA}

\section{Teori Ruang Publik Habermas}

Teori ruang publik dicetuskan oleh Jurgen Habermas. Pada tahun 1989, Habermas membuat buku yang berjudul The Structural Transformation of the public Sphere: An Inquiry into a Category of Gourgeois Society. Menurut Habermas, ruang publik adalah ruang di kehidupan sosial dimana pendapat publik bisa dibentuk dan diakses oleh semua warga negara (Darajati, 2012). Sedangkan menurut penelitian yang dilakukan Tricana, ruang publik adalah tempat di mana terjadinya pertukaran dan argumen dari berbagai gagasan budaya, eknomi, sosial, dan politik (Tricana, 2013). Ruang publik pada dasarnya merupakan ruang yang tercipta dari kumpulan orang tertentu, diciptakan sebagai bentuk penyikapan terhadap otoritas publik. Secara historis, ruang publik sudah muncul di tengah-tengah masyarakat Eropa jauh sebelum Habermas menciptakan teori ruang public. Menurut Habermas, ruang publik tidak hanya terjadi di kafe-kafe, seperti yang terjadi di Inggris, tetapi juga terjadi di tempat-tempat pertemuan khusus yang mengikutsertakan warga. Di dalam ruang publik, terjadi diskusi yang jauh lebih berbeda secara komposisi, debat yang tidak berhenti, layaknya debat kusir, dan juga orientasi dari topik diskusi diangkat sebagai fokus debat. (Nasrullah, 2015)

Sebelumnya, Prasetyo juga telah melakukan penelitian tentang pemikiran Jürgen Habermas tentang ruang publik. Penelitian ini menggunakan metode kualitatif dengan memberikan penjelasan mengenai bagaimana konsep ruang publik Hebermas berdasarkan buku The Structural Transformation of Public Sphere (selanjutnya disingkat ST), dan Between Facts and Norms (selanjutnya disingkat BFN). Menurut Prasetyo dalam ST, Hebermas menjelaskan metode kritik Imanen yang merupakan metode yang biasa dipakai para pendahulu generasi pertama Teori Kritis, seperti Horkheimer dan Ardono. Kritik imanen merupakan cara mengkritik suatu objek, dalam hal ini ruang publik. Kritik tersebut berdasarkan kepada istilah dan idealitas konsep serta nilai dari objek itu sendiri, dan tidak menggunakan nilai atau standar yang ekstern atau transenden dari objek tersebut. Tujuannya untuk menggiring dimensidimensi kekurangan atau kesalahan objek tersebut kepada apa yang disebut dengan kebenaran atau idealitas (Prasetyo, 2012). Dalam penelitian ini, disebutkan bahwa ruang publik borjuis seseugguhnya menyimpan ideal-ideal normative warisan pencerahan, solidaritas, dan persamaan (liberte, feternite, dan egalite). Jika dulu dalam masa-masa awalnya ruang publik ditempati oleh pemilik properti dan ekonomi, sekarang ruang publik diokupasi oleh orang ynag berpendapatan stabil dan pembedaan mana yang ahli dan yang tidak. Menurut Prasetyo, dalam BFN, Habermas memberikan penjelasan tidak hanya terbatas pada kaum borjuis. Habermas menekankan pentingnya ruang publik dalam konteks teori diskursus tentang hukum dan demokrasi. Ruang publik mempunyai tugas untuk merasakan, menginterperetasikan, dan mensinyalkan masalah-masalah yang ada di masyarakat. Habermas berpendapat bahwa masyarakat dapat membentuk ruang publiknya berdasarkan kelompok dan asosiasinya dalam masyarakat dengan ciri dan usungan keprihatinan masing-masing.

Menurut penelitian lainnya, ruang publik juga tidak ditentukan dengan adanya wadah fisik. Ruang publik bersifat akomodatif, sehingga dapat ada di mana saja dan kapan saja. Sifat tersebut sesuai dengan budaya pengambilan keputusan yang masih menanamkan sistem sosiokultural dengan menganggap orang yang dituakan, sangat berpengaruh dalam 
pengambilan keputusan. Orang yang lebih muda akan merasa berhati-hati untuk menyampaikan pendapatnya kepada orang yang dituakan. Ketika ingin menyanggah, orang yang lebih muda akan meyampaikan pendapatnya dengan sopan, yang pada akhirnya kemenangan keputusan mengikuti orang yang dituakan. Kuasa seperti ini terjadi melalui hegemoni dan dominasi budaya struktur Jawa. Dalam penelitian ini dapat dilihat bahwa tokoh yang dituakan, menjadi aktor yang hegemonik. (Arditama, 2016).

\section{Demokrasi}

Demokrasi akhir akhir ini jadi bahan pembicaraan, lebih tepatnya di berbagai negara berkembang dan terus terkenal, dari mulai tingkat wacana maupun dalam gerakan sosial politik. Yang dijuliki sebagai suatu sistem politik, demokrasi sudah menempati deretan teratas telah diterima oleh banyak negara karena dapat dianggap mampu mengatur dan menyelesaikan hubungan sosial dan politik, baik secara yang melibatkan kepentingan antar individu dalam masyarakat maupun hubungan antar masyarakat, masyarakat dan negara maupun antar negara di dunia. Ambruknya ideologi komunisme Uni Soviet tahun 1989, setidaknya telah menjadi momentum penting bagi perluasan demokrasi sebagai wacana pilihan sistem politik. Kepopuleran demokrasi sebagai ideologi politik secaracepat menyebar oleh berkembangnya wacana kritis yang sebagian besar mengungkapkan kegagalan praktek otoritarianisme. Hadirnya demokrasi seakan telah menjadi hal berarti dan nyata mengatasi masalah sosial politik yang selama ini diderita berbagai negara. (Nugroho, 2017)

Demokrasi merupakan bentuk pemerintahan yang memilikin kekuasaan dalam mengambil keputusan. Menurut penelitian Hallim, konsep partisipasi masyarakat dalam membentuk demokrasi dan hukum yang responsive, menjelaskan bahwa Negara demokrasi adalah Negara yang memiliki kekuasaan sipil, yang sesuai dengan keputusan rakyatnya baik secara langsung maupun tidak langsung. Pada penelitian ini, keterlibatan masyarakat dengan demokrasi liberatif, dimana kebijakan publik harus disahkan terlebih dahulu (Haliim, 2016).

Habermas mengemukakan bahwa demokrasi deliberatif hadir, jika negara memproduksi hukum yang didelegasikan melalui pola-pola pertukaran jaring-jaring sistem sosial tertentu. Namun penelitian Tobing memaparkan praktik demokrasi deliberative dalam ruang public cyber space digrup diskusi Pluaris Lembaga Bhineka, yang menengkampanyekan keberagaman dan kesetaraan melalui internet, menemukan hasil bahwa penerapan demokrasi deliberative belum maksimal secara kuantitas, karena klai perlokusi masih mendominasi lewat pendiskreditan subjek sasaran komentar (Tobing, 2013).

Perdebatan yang terjadi disebabkan bentuk demokrasi yang deliberatif, karena aturan dari ruang publik yang bebas dari dominasi, konsep demokrasi yang berkembang didalamnya, telah dilakukan dalam forum debat kaskus oleh Nugroho. Perdebatan-perdebatan yang terjadi, mementingkan musyawarah dari aktor-aktor komunikasi didalamnya. Hasil dari penelitian ini, media sosial dalam bentuk forum tidak hanya menciptakan sebuah forum ruang publik dengan gaya baru, namun juga berpotensi mengimplementasi dari konsep demokrasi deliberative didunia nyata (Nugroho, 2017.)

\section{Omnibus Law}

Sejalan dengan cyberspace, belakangan in, kata omnibus law banyak digunakan oleh pihak pemerintahan. Dalam pidatonya, Presiden Jokowi melakukan pidato menyatakan akan 
membuat hukum perundang-undanganyang dinamakan omnibus law. Omnibus Law dikenal dengan Omnibus Bill. Kata omnibus sendiri berasal dari bahasa latin yaitu omnis yang berarti banyak. Dilansir dari Kompas.com, Omnibus Law merupakan metode atau konsep pembuatan regulasi yang menggabungkan beberapa aturan yang subtansi pengaturannya berbeda menjadi satu peraturan dalam satu payung hukum karena mengatur secara menyeluruh dan memiliki daya ikat terhadap aturan yang lain. Konsep Omnibus Law sangat lazim di Amerika Serikat yang memiliki sistem hukum civil law berbeda dengan Indonesia yang sistem hukumnya merupakan common law dimana setiap undang-undang memiliki daya ikat yang sama.

Adanya omnibus law dilatar belakangi oleh banyaknya UU yang tumpang tindih di Indonesia (Kompas,18/2/2020). Dan bertujuan untuk meningkatkan daya saing dan mendorong investasi dimana selama ini banyaknya regulasi dianggap sebagai hambatan. Omnibus law sendiri akan merevisi 82 UU yang terdisi dari 1.194 pasal. RUU Omnibus law dibagi menjadi 11 klaster yaitu penyederhanaan perizinan, persyaratan investasi, ketenagakerjaan, kemudahan berusaha, kemudahan pemberdayaan dan perlindungan UMKM, dukungan riset dan inovasi, administrasi pemerintahan, pengenaan sanksi, pengadaan lahan, investasi dan proyek pemerintah, serta kawasan ekonomi dan disederhanakan menjadi tiga bagian yaitu perpajakan, cipta lapangan kerja, dan Usaha Kecil Mengengah dan Mikro (UMKM) (Efendi, 2020).

Langkah pertama yg akan diambil pemerintah adalah melakukan revisi terhadap instrumen hukum yaitu UU Nomor 15 Tahun 2019 tentang perubahan atas UU Nomor 12 Tahun 2011 tentang Pembentukan Peraturan Perundang-undangan agar memiliki legitimasi yuridis.

Dilansir dari Nasional Kontan, menurut Kemenkeu RUU Omnibus law perpajakan merupakan serangkaian kebijakan pemerintah yang dapat memperkuat perekonomian nasional melalui peningkatan pendanaan investasi dalam dan luar negeri (Santoso, 2020). Dan dilansir dari Liputan6.com, Menteri Koperasi dan Usaha Kecil Menengah menilai RUU Omnibus law UMKM bisa mendorong UMKM menjadi lebih siap daripada sebelumnya. Banyak kemudahan yang akan didapatkan seperti perizinan, pendirian, pembiayaan, dan jaminan marketnya (Santia, 2020).

Berbeda dengan Omnibus law perpajakan dan UMKM, Omnibus law ketenagakerjaan banyak menimbulkan perdebatan dibanyak kalangan. Diantaranya karena pemerintah akan merevisi beberapa aturan mengenai gaji dan pesangon, prisip kemudahan mengambil dan kemudahan memutus, dan kemudahan untuk merekrut tenaga kerja asing dan peraruran lainnya dimana banyak memperlihatkan pertemuan kepentingan pengusaha dan tenaga kerja. Omnibus law ketenagakerjaan sendiri oleh para buruh dianggap merugikan. Beberapa hal yg dianggap merugikan antara lain pengurangan nilai pesangon, pembebasan tenaga kerja asing, penggunaan outsourcing yang masif, jam kerja yang fleksibel, dan upah bulanan yang menjadi upah perjam (Efendi, 2020).

\section{METODE PENELITIAN}

Penelitian ini menggunakan pendekatan kualitatif dengan desain penelitian studi kasus. Penelitian kualitatif merupakan pendekatan untuk mengeksplorasi dan memahami individu atau kelompok yang mengenai masalah sosial atau manusia. Proses penelitian melibatkan pertanyaan yang muncul dan prosedur data yang biasanya dikumpulkan dengan melibatkan peserta, analisis data secara induktif (dari khusus ke tema umum) dan peneliti membuat 
interpretasi tentang makna data. Sedangkan desain peneltian studi kasus merupakan desain penyelidikan yang ditemukan di banyak bidang, terutama evaluasi, di mana peneliti mengembangkan analisis mendalam tentang suatu kasus, sering kali suatu program, peristiwa, kegiatan, proses, atau satu atau lebih individu (Creswell \& Creswell, 2018).

Penelitian ini menggunakan metode analisis dalam perspektif komunikasi pada demokrasi deliberatif dan berdasarkan dua teori habermas Transformasi Struktural Ruang Publik \& Antara Fakta dan Norma. Model analisis wacana ini berdasarkan pada 3 pisau analisis tidakan komunikatif yang mencakup 3 klaim. Objek yang akan diteliti yaitu diskusi yang dilaksanakan di Whatsapp. Objek yang dianalisis dalam penelitian ini yaitu, teks berupa pendapat dari Aprillia L. Tangker sebagai narasumber, Risky Egi Oktavianus, dan Yulia karena mereka bertiga yang terlibat aktif dalam diskusi tersebut. Penelitian ini sendiri menjadikan anggota yang terlibat aktif dalam memberi pendapat/opini pada setiap argumen bertema Omnibus Law di grup diskusi online yang diadakan Red Soldier FIS UNJ pada 20-21 Maret 2020 sebagai subjek.

Teknik pengumpulan data yaitu metode teks pada grup diskusi "RUU Cipta Kerja: Mengancam Ketenagakerjaan Dan Agraria Indonesia" dan "RUU Cipta Kerja: Menerobos Hukum Indonesia?". Setiap argumen/pendapat dianalisis dengan berdasar pada tiga klaim validitas, yaitu: kebenaran. ketepatan, dan kejujuran.

\section{HASIL DAN PEMBAHASAN}

Pada diskusi yang diadakan oleh Red Soldier FIS UNJ pada 20-21 Maret 2020 dengan dua tema yaitu “"'RUU Cipta Kerja: Mengancam Ketenagakerjaan Dan Agraria Indonesia” dan "RUU Cipta Kerja: Menerobos Hukum Indonesia?" terdapat 124 anggota yang terdapat pada grup diskusi di Whatsapp tersebut. Adapun yang memenuhi karakteristik yang ditentukan untuk analisis yaitu terdapat tiga orang, yaitu Aprillia L. Tangker sebagai narasumber, dan Yulia sebagai yang menanggapi pertanyaan.

\section{Klaim Kebenaran}

"Menurut LBH Jakarta, Cilaka sudah bermasalah dari awal pembuatannya hingga sekarang menjadi draft di DPR. Permasalahnnya ada pada: 1. Proses pembuatan, 2. Pasal-pasal yang ada dalam draft. Kita bahas yang pertama dulu: Proses pembuatan. RUU Cilaka dibuat menggunakan teknik omnibus law. Nah, penggunaan metode ini biasanya dilakukan oleh negara-negara Common Law seperti Inggris, USA. Omnibus Law : Di US memungkinkan suatu RUU Terpadu (omnibus bill), yang berisi perubahan atau bahkan penggantian beberapa UU sekaligus, diajukan ke parlemen untuk mendapat persetujuan dalam satu kesempatan pengambilan keputusan. Kelebihan hanyalah dan tak lebih dari sifatnya yang multisektor dan waktu pembahasannya yang bisa lebih cepat." -Aprillia L. Tangker (Narasumber)

"Jadi, kenapa metode ini digunakan? Karena pemerintah sedang membutuhkan penyederhanaan regulasi untuk memuluskan masuknya investasi di Indonesia. Aturan terkait investasi sangat banyak dan dianggap menyulitkan dunia usaha. Mau pakai metode revisi seperti biasa pasti makan waktu. Makanya pemerintah akhirnya membuat RUU Cilaka pakai omnibus law. Sayangnya, metode ini tidak dikenal di sistem hukum Indonesia. Kita pakai Civil 
Law yang identik dengan kedifikasi peraturan perundang-undangan. Jika Pak Presiden menginginkan RUU Cilaka disahkan pada saat Lebaran (Beliau selalu bilang kalo RUU ini akan menjadi kado lebaran), maka cara pembuatan ini tidak dapat dilakukan. Mengapa? Karena akan banyak peraturan yang harus diubah dalam waktu cepat yang akan sulit dalam pengawasan perubahannya. Ada Perda, Peraturan tingkat menteri, PP, dan lainnya yang harus dipetakan dengan jelas. Menurut Prof. Maria (Guru besar FHUI) metode ini tidak dapat digunakan di Indonesia karena tidak ada peraturan yang sebenarnya mengatur ini." -Aprillia L. Tangker (Narasumber)

"Mengutip kertas kebijakan HUMA: Secara formil, prosedur penyusunan omnibus law tunduk pada ketentuan tentang penyusunan undang-undang. Artinya, penyusunan omnibus law untuk konteks Indonesia harus sesuai dengan UU 12/2011 tentang Pembentukan Peraturan Perundang-Undangan. Penyusunan undang-undang yang bertentangan dengan UU 12/2011 dapat dikatakan mengandung cacat formil."omnibus law sebagai strategi tidak memenuhi tujuan substantif dari demokrasi. Di Amerika Serikat misalnya, Krutz mengidentifikasi beberapa karakteristik dari praktik-praktik omnibus law, di antaranya: (a) biasanya pasalpasal kontroversial akan lengah dari perhatian jika disisipkan dalam omnibus law. Hal ini karena pasal-pasal yang diatur dalam omnibus terlalu banyak dan kompleks, sehingga banyak aturan detail yang berbahaya bagi kepentingan masyarakat luput dari perhatian; (b) omnibus law yang memuat berbagai pasal membatasi pilihan anggota legislatif. Karena sifat pengaturannya yang detail dan kompleks, ada pasal-pasal kontroversial yang terpaksa disetujui anggota legislatif karena ada pasal-pasal lainnya yang memenuhi kepentingan anggota; (c) meskipun secara formil mematuhi prosedur penyusunan undang-undang, namun tendensi penyusun omnibus law yang berorientasi waktu selalu membatasi partisipasi publik dalam memberikan masukan" -Aprillia L. Tangker (Narasumber)

"Coba, di sini siapa pengurus BEM? Pasti punya semacam SOP atau peraturan internal kan? Biasanya, aturan itu akan disusun bersama-sama atau perwakilan anggota supaya prosesnya demokratis. Jika proses hanya dilakukan oleh pengurus harian BEM, hasilnya tidak akan demokratis dan yg pasti penuh dengan kepentingan pribadi si pembuat, walau aturannnya diberlakukan untuk semua anggota. Aturan seperti itu menunjukan jika kepemimpinan yang ada adalah kepemimpinan yg otoriter. Begitu pun dengan RUU Cilaka yang dibuat hanya mengikutsertakan pemerintah dan pengusaha. Hasilnya tidak demokratis karena tidak ada partisipasi masyarakat luas yang pasti akan sangat terdampak. Pemerintah bikin Satgas Omnibus Law Cilaka yg isinya pemerintah, rektor-rektor kampus dan pengusaha. Ketuanya dari pengusaha. Padahal RUU ini akan berdampak pada: buruh, mahasiswa, petani, nelayan, masyarakat adat, penduduk desa maupun kota, TKI, dan masih banyak lagi. Tapi, tidak ada yang diajak. Mungkin teman-teman sudah baca liputan majalah Tempo. Semua yang ada dalam tim dan pegang draft harus tanda tangan surta perjanjian tidak boleh menyebarkan draft RUU Cilaka. Setauku belum pernah ada hal-hal seperti itu. Buat apa coba? Ku kembalikan ke moderator" -Aprillia L. Tangker (Narasumber)

"Menanggapi Pasal 170 yang kontroversial, apakah hal tersebut benar dan dapat saja terjadi di hukum Indonesia? Dan mengenai Omnibus Law ini terdapat isu sentralisasi kekuasaan, apakah hal ini ada hubungannya dengan kepentingan pemerintah pusat? Yang didalamnya juga memang banyak yang menjadi investor besar di Indonesia" -Risky Egi Oktavianus

"Nah, pasal 170 RUU Cilaka kacau dan melanggar sistem hukum dan tata urutan perundangundangan Indonesia. Tidak bisa Peraturan Presiden mengubah sebuah UU. Urutan UU lebih 
tinggi dari PP. Katanya kan TYPO, tapi kita meragukan alasan tersebut. Bisa jadi semangat awalnya bias kendali di pusat. btw, investor juga ad di daerah kok. Ini kayak rebutan kue aja" - Aprillia L. Tangker (Narasumber)

"Tadi sempat disebutkan kalau RUU cilaka ini dibuat untuk memuluskan investasi ke indonesia. Pertanyaan saya adalah memang seberapa ribetkah peraturan yang berlaku di indonesia terkait investasi, sehingga alasan memuluskan investasi menjadi senjata utama pemerintah dalam menjawab publik mengenai RUU ini, atau mungkin ada kepentingan pihak tertentu di balik ini ? Terimakasih" - Risky Egi Oktavianus

"Kalo seberapa ribet gw ga tau pasti. Tapi yg pasti banyak aturan yg dibuat. Ada aturan yg bagus buat melindungi kelompok marjinal yg dapat terdampak. Contoh: aturan izin lingkungan, aturan PHK, sanksi pidana dll. Tapi di pelaksanaannya kan yang sudak bermasalah. Jadi bahan buat korupsi. Kalo kepentingan pasti ada, tapi siapa? Sebenarnya dengan eksekutif dan legislatif yg 1 suara sepakat sama RUU ini kita uda bisa lihat kok. Tumben kan mereka akur, padahal pas kemarin Pemilu berantemnya gila2an" - Aprillia L. Tangker (Narasumber)

Pada chat teks tersebut Aprillia sebagai narasumber memaparkan materi sesuai dengan tema yang sedang dibahas yaitu Omnibus Law dan terjadinya tanya jawab pada anggota grup diskusi tersebut. Jadi hal tersebut sudah memenuhi klaim kebenaran dalam ruang diskusi.

\section{Klaim Ketepatan}

"Pembahasan kedua: Pasal-pasal di dalam draft. Kawan-kawan serikat buruh sudah banyak protes tentang pasal di kluster ketenagakerjaan. Kita bisa temuin banyak hal, yang paling sederhana contohnya cuti haid. Di sini ada yang ibunya bekerja sebagai buruh? karyawati? Pasti tahu gimana rasanya bekerja pada saat menstruasi. Nah, tidak semua buruh perempuan tahu kalau dia punya hak minta cuti hadi sesuai UU Ketenagakerjaan. Jika praktik sekarang, kita masih bisa nuntut ke perusahaan jika tidak dikasih. Nah, jika RUU Ciilaka sah akan beda cerita. Cuti haid bukan lagi jadi hak yang secara jelas ada dalam UU. Dia dapat dimintakan jika itu masuk dalam perjanjian kerja, peraturan perusahaan, atau perjanjian kerja bersama. Jika itu tidak diatur, pas kita minta tidak akan dikasih dengan alasan tidak ada aturannya. Dari kluster yang lain seperti perizinan. Contohnya izin lingkungan akan diubah dalam bentuk lain dan ke depan korban terdampak tidak bisa menggugat izin lingkungan. Contoh kasus Kendeng. Warga berhasil menggugat izin lingkungan pabrik semen sehingga pabrik tidak dapat beraktivitas. Beberapa pasal pidana akan dikecilkan kekuatannya dan akan didahului oleh sanksi administrasi. Kita tau bagaimana bebalnya pengusaha di sini. Sudah ada sanksi pidana saja masih berani dilanggar. Seperti kasus pembakaran lahan 2019 kemarin. Lalu apa yang bisa dilakukan sebelum draft RUU Cilaka disahkan? Menurut LBH Jakarta kita harus menolak total RUU ini. Jangan sampai disahkan. Kita belajar Revisi UU KPK aja. Kita dari awal menolak untuk direvisi dan tidak memilih pasrah dan langsung bilang nanti di JR aja. kenapa? karena kita tahu JR bukan pilihan mudah. Belum ada sejarah di indonesia JR langung menghapus satu UU. JR dilakukan untuk pasal -pasal yg dianggap bertentangan. UU KPK saja tetap sulit kan pas di JR. Mau tuntut terbitin perpu? Tidak mungkin mau" --Aprillia L. Tangker (Narasumber)

Pada chat teks tersebut Aprillia sebagai narasumber memaparkan materi sesuai dengan tema yang sedang dibahas yaitu dimana isu pengesahan Omnibus Law merupakan hal yang krusial saat ini dan adanya ketepatan secara normatif terbukti pada pembicaraan narasumber, yaitu: 
"Kawan-kawan serikat buruh sudah banyak protes tentang pasal di kluster ketenagakerjaan. Kita bisa temuin banyak hal, yang paling sederhana contohnya cuti haid. Di sini ada yang ibunya bekerja sebagai buruh? karyawati? Pasti tahu gimana rasanya bekerja pada saat menstruasi. Nah, tidak semua buruh perempuan tahu kalau dia punya hak minta cuti hadi sesuai UU Ketenagakerjaan. Jika praktik sekarang, kita masih bisa nuntut ke perusahaan jika tidak dikasih. Nah, jika RUU Ciilaka sah akan beda cerita. Cuti haid bukan lagi jadi hak yang secara jelas ada dalam UU. Dia dapat dimintakan jika itu masuk dalam perjanjian kerja, peraturan perusahaan, atau perjanjian kerja bersama. Jika itu tidak diatur, pas kita minta tidak akan dikasih dengan alasan tidak ada aturannya. - Dari kluster yang lain seperti perizinan. Contohnya izin lingkungan akan diubah dalam bentuk lain dan ke depan korban terdampak tidak bisa menggugat izin lingkungan. Contoh kasus Kendeng. Warga berhasil menggugat izin lingkungan pabrik semen sehingga pabrik tidak dapat beraktivitas. - Beberapa pasal pidana akan dikecilkan kekuatannya dan akan didahului oleh sanksi administrasi. Kita tau bagaimana bebalnya pengusaha di sini. Sudah ada sanksi pidana saja masih berani dilanggar. Seperti kasus pembakaran lahan 2019 kemarin. Lalu apa yang bisa dilakukan sebelum draft RUU Cilaka disahkan? Menurut LBH Jakarta kita harus menolak total RUU ini. Jangan sampai disahkan. Kita belajar Revisi UU KPK aja. Kita dari awal menolak untuk direvisi dan tidak memilih pasrah dan langsung bilang nanti di JR aja. kenapa? karena kita tahu JR bukan pilihan mudah. Belum ada sejarah di indonesia JR langung menghapus satu UU. JR dilakukan untuk pasal -pasal yg dianggap bertentangan. UU KPK saja tetap sulit kan pas di JR. Mau tuntut terbitin perpu? Tidak mungkin mau"

Klaim ketepatan dapat berupa norma umum atau spesifik yang diyakini pembicara (Tobing, 2013). Secara spesifik, klaim normatif juga diyakini oleh peserta forum diskusi yang menanggapi yang didominasi oleh kritik terhadap Omnibus Law. Terdapat kesan mengkritik terhadap pihak yang bersangkutan dalam pembuatan Omnibus Law seperti yang diungkapkan oleh Aprillia "Jika praktik sekarang, kita masih bisa nuntut ke perusahaan jika tidak dikasih. Nah, jika RUU Ciilaka sah akan beda cerita. Cuti haid bukan lagi jadi hak yang secara jelas ada dalam UU." dan membela pihak yang tenaga kerja terutama buruh yang akan dirugikan seperti ungkapan "jika RUU Ciilaka sah akan beda cerita. Cuti haid bukan lagi jadi hak yang secara jelas ada dalam UU. Dia dapat dimintakan jika itu masuk dalam perjanjian kerja, peraturan perusahaan, atau perjanjian kerja bersama. Jika itu tidak diatur, pas kita minta tidak akan dikasih dengan alasan tidak ada aturannya. - Dari kluster yang lain seperti perizinan. Contohnya izin lingkungan akan diubah dalam bentuk lain dan ke depan korban terdampak tidak bisa menggugat izin lingkungan." , hal tersebut terdapat pada pembicaraan narasumber. Jadi hal tersebut sudah memenuhi klaim ketepatan dalam ruang diskusi.

\section{Klaim Ketulusan}

"Kawan2 serikat buruh uda banyak protes tentang pasal di kluster ketenagakerjaan. Kita bisa temuin banyak hal. Yg paling sederhana deh contohnya cuti haid. Di sini ada yg ibunya bekerja sebagai buruh? karyawati? Pasti tahu gimana rasanya bekerja pada saat menstruasi. Nha, tidak semua buruh perempuan tahu kalau dia punya hak minta cuti hadi sesuai UU Ketenagakerjaan. Klo praktik sekarang, kita masih bisa nuntut ke perusahaan jika ga dikasih. Nah, klo RUU Ciilaka sah akan beda cerita. Cuti haid bukan lagi jadi hak yang secara jelas ada dalam UU. Dia daapt dimintakan jika itu masuk dalam perjanjian kerja, peraturan perusahaan, atau perjanjian kerja bersama. Kalo itu ga diatur, pas kita minta ga bakalan dikasih dengan alasan ga ada aturannya." - Yulia (Peserta Diskusi) 
Tanggapan-tanggapan yang diutarakan Yulia di ruang diskusi mengandung dua hal yang mengandung klaim ketulusan, diantaranya:

- Adanya ungkapan emosional yang di utarakan demi membela kaum tenaga kerja yang dirugikan (Tobing, 2013). Yang terdapat dalam ungkapan "Klo praktik sekarang, kita masih bisa nuntut ke perusahaan jika ga dikasih. Nah, klo RUU Ciilaka sah akan beda cerita. Cuti haid bukan lagi jadi hak yang secara jelas ada dalam UU. Dia daapt dimintakan jika itu masuk dalam perjanjian kerja, peraturan perusahaan, atau perjanjian kerja bersama. Kalo itu ga diatur, pas kita minta ga bakalan dikasih dengan alasan ga ada aturannya."

- Adanya dukungan subjektif terhadap penolakan Omnibus Law. Perkataan yang subjektif terdapat dalam kalimat "Kawan2 serikat buruh uda banyak protes tentang pasal di kluster ketenagakerjaan. Kita bisa temuin banyak hal. Yg paling sederhana deh contohnya cuti haid. Di sini ada yg ibunya bekerja sebagai buruh? karyawati? Pasti tahu gimana rasanya bekerja pada saat menstruasi."

\section{Analisis Berdasarkan dua Teori Habermas}

\section{"The Structural Transformation of Public Sphare": Ruang Publik Borjuis (ST)}

Menurut Habermas dalam ST, ruang publik dibedakan menjadi dua yaitu ruang publik yang dikooptasi kekuasaan yaitu ruang publik yang tumbuh dari dunia kehidupan dan yang kedua yaitu yang publik yang dikooptasi oleh kekuasaan sebagai ruang publik yang berorientasi pada wilayah sistem, yakni pasar dan administrasi. Ruang publik yang dikooptasi oleh kekuasaan didominasi oleh para aktor pemakai, yakni aktor-aktor yang tidak tumbuh didalam publik melainkan hadir di depan publik dan menduduki ruang publik dimana mereka memanfaatkan medium uang serta kekuasaan mereka untuk memperalat publik. Mereka yang menjadi aktor biasanya memiliki identitas sosial yang diakui dan mapan dalam masyarakat. Sedangkan ruang publik yang tumbuh dari dunia kehidupan dikuasai oleh aktor-aktor yang tidak dikooptasi kekuasaan yaitu pribumi, karena mereka berasal dari publik itu sendiri. (Prasetyo, 2012)

Ruang publik yang terjadi di ruang diskusi online yang membahas tentang omnibus law merupakan ruang publik yang tidak dikooptasi yaitu ruang publik yang terdiri dari banyak orang yang hadir dalam ruang publik itu sendiri diantaranya mahasiswa dari Universitas Negeri Jakarta dari berbagai FIS UNJ, FBS UNJ, FKIP UNSIL, FISIP UNSIKA, FITK IAIN CRB, FKIP UNJA, FKIP UNTAD, FKIP GJ, FIP UNJ, FAPERTA UNSIL, FPIPS UPI, GEO UGM, FPIP UNIRA, FAI UNSIL, UPI Tasik, AUS Bekasi, FH UI, bukan terdiri dari orang-orang yang memiliki identitas sosial yang diakui sehingga dapat memperalat publik seperti ruang publik pemerintahan yang tetap berpendapat bahwa Omnibus Law harus tetap disahkan sementara banyak pihak tenaga kerja yang akan dirugikan.

\section{“Between Facts and Norms": Ruang Publik dalam Demokrasi Deliberatif (BFN)}

Dalam BFN, Habermas memberikan penjelasan akan pluralitas ruang publik. Setiap komunitas dapat dan kelompok dapat membentuk ruang publiknya sendiri yang secara koseptual, ruang publik dipahami sebagai jaringan yang kompleks dan terdiferensiasi namun yang mengkonstitusi dirinya sebagai "teks tunggal" dengan tujuan untuk mengamankan kapasitas individu-individu dalam rangka untuk mendapatkan pengakuan atau legitimasi atas kemasukakalan dan keadilan dari pandangan yang mereka utarakan. (Prasetyo, 2012) 
Dalam ruang diskusi yang sedang kita bahas ini juga mengutamakan pluralitas yaitu dibentuk untuk mendapatkan pengakuan dan keadilan dengan pandangan-pandangan yang seringkali diutarakan. Seperti yang diutarakan oleh Yulia sebagai peserta diskusi:

"Begitu pun dengan RUU Cilaka yg dibuat hanya mengikutsertakan pemerintah dan pengusaha. Hasilnya tidak demokratis karena tidak ada partisipasi masyarakat luas yg pasti akan sangat terdampak. Pemerintah bikin Satgas Omnibus Law Cilaka yg isinya pemerintah, rektor2 kampus, sama pengusaha. Ketuanya dari pengusaha. Padahal RUU ini akan berdampak pada: buruh, mahasiswa, petani, nelayan, masyarakat adat, penduduk desa maupun kota, TKI, dan masih banyak lagi. Tapi, ga ada yg diajak."

Dari ungkapan tersebut, Yulia terlihat bahwa pandangannya terhadap Omnibus Law RUU Ciptaker ingin orang-orang didalam ruang diskusi setuju bahwa RUU Ciptaker sangat tidak adil karena tidak terdapat partisipasi dari masyarakat luas dalam pembuatannya.

Dari pembahasan tersebut kita dapat melihat bagaimana diskusi publik yang diadakan oleh Red Soldier FIS UNJ dilaksanakan pada 20-21 Maret 2020 dengan pemantik diskusi Sujak Supriyadi dari Ka. Seni dan Budaya DPP-GBSI serta Aprillia Lisa Tengker dari Pengacara Publik LBH Jakarta dari pandangan kebenaran, ketepatan, kejujuran serta bagaimana dua teori habermas sendiri yaitu ST dan BFN memandang diskusi publik tersebut.

\section{E. KESIMPULAN}

Ruang publik untuk berdiskusi tentang kebijakan pemerintah masih sangat terbatas. Sebagai contoh, diskusi tentang omnibus law yang merupakan kebijakan yang krusial saja dilakukan oleh mahasiswa dan para aktivis melalui situs online yang tidak formal, sebut saja salah satunya adalah kaskus. Di kaskus sendiri peserta forum terdiri dari berbagai kalangan, yaitu mahasiswa, aktivis, pegiat sosial, pebisnis, dan lain lain. Di dalam forum terbuka tersebut meskipun terdapat berbagai kalangan yang ikut berpartisipasi dalam diskusi, akan tetapi tidak ada pihak dari pemerintah yang ikut serta di dalamnya.

Omnibus law dianggap memberatkan pihak dari golongan buruh, mahasiswa, petani, nelayan, masyarakat adat, penduduk desa maupun kota, dan lebih mengedepankan kepentingan investor dan pengusaha. Hal yang mengundang kontroversi seperti itu pun pemerintah masih tidak memberikan fasilitas yang maximal bagi masyarakat untuk berdiskusi dan menyuarakan pendapatnya. Demo yang diadakan pun hanya sekedar mengumpulkan massa, menyuarakan pendapat, lalu masuk telinga kanan dan keluar ke dari telinga kiri oleh pemerintah. Masyarakat lebih membutuhkan ruang publik dimana mereka bisa berdiskusi dengan pemerintah, memberikan masukan, dan saling bahu membahu dalam membangun negeri.

\section{F. DAFTAR PUSTAKA}

Arditama, E. (2016). Mengkaji Ruang Publik dari Perspektif Kuasa: Fenomena Kemenangan Aktor Hegemonik Melalui Dominasi Budaya. Politik Indonesia: Indonesian Political Science Review, 1(1), 69. https://doi.org/10.15294/jpi.v1i1.9181

Creswell, J. W., \& Creswell, J. D. (2018). Research and Design Qualitative, Quantitative and Mixed Methods Approaches. In Thousand Oaks California.

Darajati, Z. K. (2012). Gerakan Sosial Mahasiswa Komunikasi FISIP Universitas Airlangga

Pada Ruang Publik Facebook. Jurnal Sosial Dan Politik, 2.

Efendi. (2020). Omnibus Law dan Ketenagakerjaan Nasional. Jurnal Social Security, 1, 2. 
Gatara, A. (2016). Demokrasi Nothing Kritik Terhadap Konsep Dan Praktek

Cyberdemocracy. Dialog Kebijakan Publik, 1-11.

Haliim, W. (2016). Demokrasi Deliberatif Indonesia : Konsep Partisipasi Masyarakat Dalam Membentuk Demokrasi Dan Hukum Yang Responsif. Jurnal Masyarakat Indonesia, 42(1), 19-30.

Jati, W. R. (2016). Cyberspace, Internet, Dan Ruang Publik Baru: Aktivisme Online Politik Kelas Menengah Indonesia. Jurnal Pemikiran Sosiologi, 3(1), 25. https://doi.org/10.22146/jps.v3i1.23524

Nasrullah, R. (2015). Internet dan Ruang Publik Virtual, Sebuah Refleksi atas Teori Ruang Publik Habermas. Komunikator, 4 (1).

Nugroho, S. (2017). Demokraso Deliberatif. Universitas Airlangga.

Pembayun, J. G. (2017). Rekonstruksi Pemikiran Habermas Di Era Digital. 1, No. l(Oktobber), 1-14.

Prasetyo, A. (2012). Menuju Demokrasi Rasional: Melacak Pemikiran Jurgen Habermas Tentang Ruang Publik. Jurnal Ilmu Sosial Dan Ilmu Politik, 16(2), 37770.

Santia, T. (2020). Omnibus Law Bikin UMKM Berdaya Saing. Jakarta.

Santoso, Y. I. (2020). Sah! RUU omnibus law perpajakan berisi sembilan undang-undang. Jakarta.

Sukmono, F. G. (2009). Ruang Publik Alternatif dalam Cyber Space. 3(1), 132-139.

Tobing, A. W. L. (2013). Demokrasi Deliberatif Dalam Ruang Publik Cyber Space (Analisis Wacana Demokrasi Deliberatif dalam Ruang Publik pada Komentar Kiriman Bertema UU Pemilukada, UU MD3 dan Perseteruan KMP dan KIH di Grup "Diskusi PluralismeLembaga Bhinneka” Facebook). Journal of Chemical Information and Modeling, 53(9), 1689-1699. https://doi.org/10.1017/CBO9781107415324.004

Tricana, D. W. (2013). Media Massa Dan Ruang Publik (Public sphere), Sebuah Ruang Yang Hilang. Aristo, 1(1), 8. https://doi.org/10.24269/ars.v1i1.1538 